Article

\title{
Jatropha curcas, L. Pruning Residues for Energy: Characteristics of an Untapped By-Product
}

\author{
Luigi Pari, Alessandro Suardi * (1), Leonardo Longo, Monica Carnevale and Francesco Gallucci \\ Consiglio per la Ricerca in Agricoltura e l'Analisi dell'Economia Agraria (CREA)—Centro di Ricerca Ingegneria \\ e Trasformazioni Agroalimentari (Council for Agricultural Research and Economics-Research Centre for \\ Engineering and Agro-Food Processing), via della pascolare 16, 00015 Monterotondo, Roma, Italy; \\ luigi.pari@crea.gov.it (L.P.); leonardo.longo@crea.gov.it (L.L.); monica.carnevale@crea.gov.it (M.C.); \\ francesco.gallucci@crea.gov.it (F.G.) \\ * Correspondence: alessandro.suardi@crea.gov.it; Tel.: +39-06-90675-248
}

Received: 28 March 2018; Accepted: 19 June 2018; Published: 21 June 2018

\begin{abstract}
Jatropha (Jatropha curcas, L.) is an energy crop mainly cultivated for the oil-seed, and the oil is usually used as bio-fuel. However, few studies have reported information about the utilization of the wood as a fuel for boiler heating systems. With 2500 jatropha trees per hectare, it is possible to produce about $3 \mathrm{t} \cdot \mathrm{ha}^{-1} \cdot \mathrm{y}^{-1}$ of woody biomass from pruning. In addition, jatropha trees are commonly cut down to a height of $45 \mathrm{~cm}$ once every 10 years, with a production of $80 \mathrm{t} \cdot \mathrm{ha}^{-1}$ of dry matter of woody biomass. The use of this biomass has not yet been investigated. During the European project JatroMed, woody biomass from jatropha pruning was collected in Morocco. Chemical and physical characteristics of the wood were conducted according to UNI EN ISO standards. The following jatropha wood characteristics have been analyzed: Moisture and ash contents, the ash melting point, heating value, and concentrations of $\mathrm{C}, \mathrm{H}, \mathrm{N}$, and $\mathrm{S}$. This research focused on the evaluation of the potential use of jatropha pruning for energy production, and the results represent critical data that is useful for future studies and business potential.
\end{abstract}

Keywords: Jatropha curcas, L.; physic nut; wood pruning; chemical and physical characteristics; residues

\section{Introduction}

Biomass represents a renewable source of primary energy that will increase in importance in future global energy scenarios [1]. Agricultural residues represent a good potential source of biomass, as well as a potential market of pruning residues that are currently considered to be waste [2].

Pruning is one of the most important forms of tree maintenance, which helps the production of more branches and stimulates abundant and healthy inflorescence, thus eventually enhancing good fruit setting and seed yield [3]. However, branches and shoots regularly produced are considered a problem rather than an opportunity and, hence, they are not used or incorrectly disposed of [4]. Traditionally, pruning residues are disposed of through open-air burning, releasing a variety of pollutants [5]. At a landscape level, localized emissions generated by this practice can be substantial, especially for heavy particulate [6]. Additionally, as reported by Reference [7], field burning is labor-intensive and incurs significant cost. If prunings are not burned, in the best-case scenario, they are mulched or just left at the edge of the field, wasting a potentially profitable business for farmers, logistic companies, and final users. Therefore, finding some use for pruning residues would turn a disposal problem into a collateral production, with the potential for revenues or reduced management costs [8].

Moreover, global warming and climate change caused by increased greenhouse gases (GHG) emissions that are mainly due to energy production [9], and the increased fossil fuel price that has 
resulted from the growth in worldwide demand for energy, have become major concerns for many countries [10]. Mediterranean countries have a high energy dependence and their average use of fossil fuels is $80 \%$, or $85 \%$ if fossil fuel producer countries are taken into account [10].

The energy use of residues complies with the aims of EU Directives that promote a global target of $20 \%$ renewable energy in total energy consumption by 2020 [11], and biomass can deliver significant and cost-effective greenhouse gas reductions in electricity, heat, and transport fuel supply [12].

Concerns regarding food security, displacement of food crop production, and indirect land use change (iLUC) have led to the introduction of measures to reduce the use of first-generation biofuels and promote so-called advanced biofuels based on feedstocks that do not compete with food/feed crops, such as waste and agricultural residues. However, it must be highlighted that, for agricultural and forestry residues, some amount of material should be left on site under sustainable harvesting practices to protect against soil erosion and soil carbon loss. Some agricultural residues have other existing uses, including livestock bedding and feed, mushroom cultivation, and horticultural uses, and should not be considered available for biofuel [13-15].

Jatropha curcas, L. is a small tree of the Euphorbiaceae family that is cultivated to produce oil-seed. The oil is not edible [3,4] and can be used directly with slow-speed diesel engines or upgraded via transesterification to conventional biodiesel [16], but could also be used to produce soap [17]. In addition to the oil production, jatropha is a multi-functional plant from which it is possible to obtain interesting by- and co-products [18-21]. The press cake is used as fertilizers or for animal feed (after detoxification processes) $[20,22]$. The bark has medicinal value, and the flowers can be pollinated by bees to produce honey [17]. As observed by Reference [17], more studies should be focused on identification of the services and by-products obtainable by jatropha.

Jatropha prunings are a woody residue that are not extensively studied and could represent an important resource for the farmer. In fact, there is not much information about the use of jatropha wood. According to References [22,23], the jatropha wood is not appropriate for combustion due to its low density and high combustion level. In addition, the conversion of the jatropha wood in bio-char is not economically convenient either [22,23].

According to Reference [24], 2500 trees can be planted in one hectare, meaning a potential production of $20 \mathrm{Mg} \cdot \mathrm{ha}^{-1}$ of wood in six years [25]. Furthermore, it is common practice to cut the jatropha trees at $450 \mathrm{~mm}$ from the ground every 10 years for a future growing cycle. This practice can produce up to $80 \mathrm{t} \cdot \mathrm{ha}^{-1}$ of dry matter every 10 years [26].

Previous studies highlight that jatropha wood utilization for energy is not economically sustainable. However, it is a fact that pruning is a necessary activity, and the wood pruning residue, if not used, must be disposed of at a cost. Moreover, to the best of our knowledge, there are no studies in the literature that discuss jatropha wood characterization and that have investigated its potential use as a renewable source in thermochemical processes.

This research has analyzed the potentiality of jatropha wood prunings as a biofuel, beginning with its chemical and physical characteristics. Advantages and disadvantages have been compared and jatropha pruning uses have been highlighted to revalue a resource that is currently untapped.

\section{Materials and Methods}

This study evaluates the potential utilization of jatropha prunings for energy production. Physical-chemical characterizations were carried out to verify the suitability of its wood as a biofuel for industrial boilers.

The physicochemical characterization analyses were performed at the Laboratory for Experimental Activities on Renewable Energy from Biomass (LAS-ER-B) of CREA-IT of Monterotondo (Rome, Italy) on a total of 40 samples randomly collected from 20 jatropha trees three years of age of the Mali genotype (Figure 1).

The wood samples were collected from the experimental fields of the "Centre de Developpement de la Region de Tensift" (CDRT) near Essaouira (Morocco). The samples were secondary branches 
with an average diameter of $2.5 \mathrm{~cm}$ in the basal part and $0.8 \mathrm{~cm}$ in the apical part. With water or thermal stress, jatropha plants tend to lose their leaves and then re-create them during the beginning of the hot season. For this reason, the samples were without leaves. In this study, the jatropha wood was characterized in order to obtain useful data for possible energy usage in combustion plants. In particular, analysis has regarded the moisture content (MC), the higher and lower heating value (HHV and LHV), the ash content (AC), the ash melting point (AMP), and the elemental analysis (CHNS). Each type of analysis was carried out on five sub-samples of jatropha wood and descriptive statistics were used to describe the basic features of the data obtained by the analysis (Table 1).

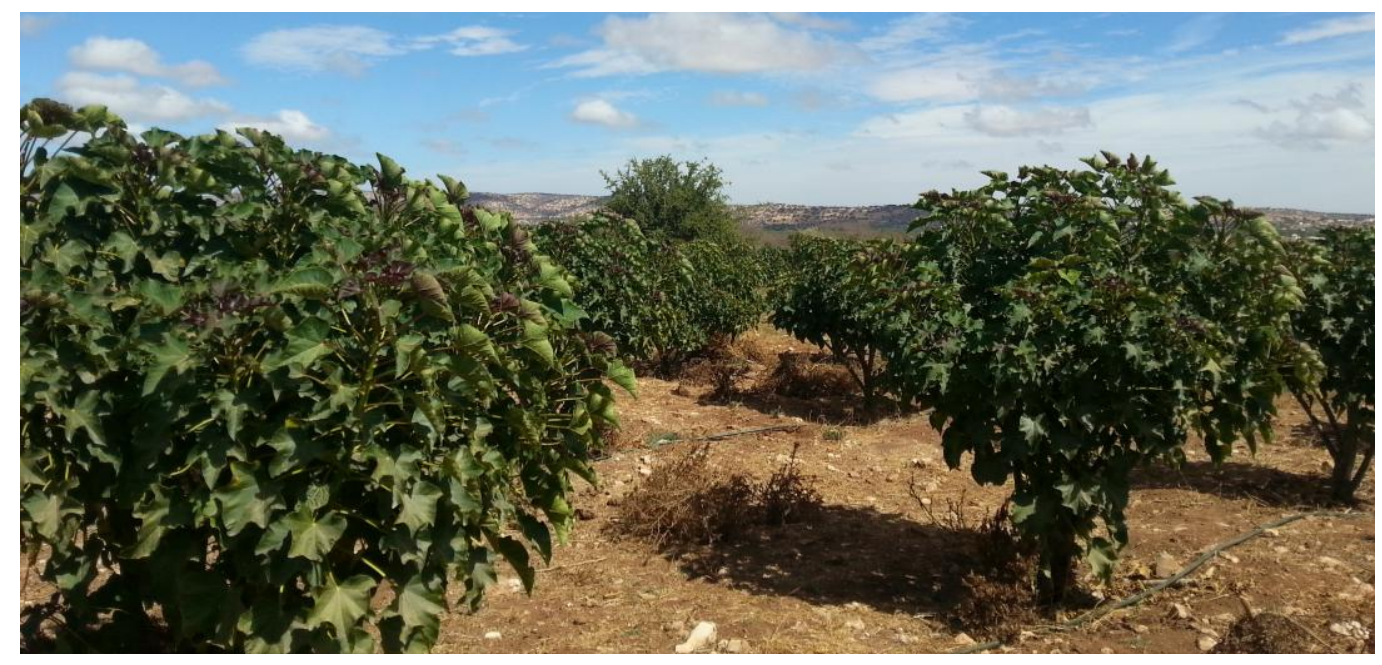

Figure 1. Picture of the three years old jatropha plants of the Mali genotype where the pruning wood samples were collected ( $31^{\circ} 33^{\prime} 13.6^{\prime \prime} \mathrm{N} 9^{\circ} 32^{\prime} 44.0^{\prime \prime} \mathrm{W}-$ Morocco).

\subsection{Moisture Content (MC)}

The moisture content as received (Mar) was determined according to UNI EN 14774-2 [27]. The samples, after being weighed, were placed in a Memmert UFP800 drying oven (Schwabach, Germany) at a temperature of $105( \pm 2){ }^{\circ} \mathrm{C}$ for $24 \mathrm{~h}$ (until complete drying of the material).

\subsection{Higher and Lower Heating Value (HHV and LHV)}

The HHV represents the amount of thermal energy generated by the combustion of one $\mathrm{kg}$ of dry matter (considering the water in biomass at atmospheric pressure and at a liquid state of $15^{\circ} \mathrm{C}$ ) [28]. The determination of the HHV was performed with an Anton Parr isoperibol calorimeter, according to UNI EN ISO 18125 [29]. In particular, the dried sample was ground first with a Retsch SM 100 cutting mill (Haan, Germany) for a preliminary size reduction and, thereafter, through a Retsch ZM 200 rotor mill. Hence, the sample was prepared in pellet form of about $1 \mathrm{~g}$ through a pellet press and then it was inserted into the bomb calorimeter. The sample was connected through a cotton wire to the electrodes for the ignition of the combustion reaction that occurs in a high-pressure oxygen atmosphere. The lower heating value (LHV) was calculated from the higher heating value, depending on the hydrogen content.

\subsection{Ash Content}

The determination of the ash content was carried out according to UNI EN 14775 [30], using a Lenton EF11/8B muffle furnace (Hope, UK). The sample, of about $1 \mathrm{~g}$, was placed on a porcelain dish and then inserted in the furnace. The crucibles containing the samples were heated in the oven raising the temperature by $7.5^{\circ} \mathrm{C}$ per minute up to $250{ }^{\circ} \mathrm{C}$ and left at this temperature for one hour. Then the temperature was increased by $10^{\circ} \mathrm{C}$ per minute up to $550{ }^{\circ} \mathrm{C}$ for $120 \mathrm{~min}$. 


\subsection{Ash Melting Point}

The ash melting point was evaluated according to the UNI CEN/TS 15370-1 [31] by a furnace SYLAB SHV-IF 1500 (Metz, France). This furnace can reach a temperature of $1600{ }^{\circ} \mathrm{C}$ and is equipped with a camera which measures ash deformation temperatures (start, deformation, hemispherical, and fluid). The samples of ash with a maximum particle size of $0.075 \mathrm{~mm}$ were compressed in a die to form cylindrical pellets with a height and diameter of 3-5 $\mathrm{mm}$.

\subsection{Elemental Analysis}

The total carbon $(\mathrm{C})$, hydrogen $(\mathrm{H})$, nitrogen $(\mathrm{N})$, and sulfur $(\mathrm{S})$ were obtained with a Costech ECS 4010 CHNS-O elemental analyzer (Valencia, CA, USA), according to UNI EN 15104 [32]. Tin capsules containing about $1 \mathrm{mg}$ of sample were prepared and then inserted in the combustion furnace of the analyzer through a pneumatic carousel. The oxygen content $(\mathrm{O})$ was calculated by difference on a dry basis.

The element ratios $(\mathrm{C} / \mathrm{N}, \mathrm{H} / \mathrm{C}$ and $\mathrm{O} / \mathrm{C})$ were calculated by dividing the mass of the elements (\%) and their own atomic weight, in line with Reference [33].

\section{Results}

Results of the characterization are reported in Tables 1 and 2. Jatropha wood has been compared with both the laboratory analysis results that referred to grapevine prunings (Vitis vinifera, L.) [34], olive tree prunings (Olea europaea, L.), and giant reed (Arundo donax, L.), and with literature data on cardoon (Cynara cardunculus, L.) biomass (stem and leaves) [35]. This comparison with other types of biomass has been carried out in order to evaluate the characteristics of jatropha related to lignocellulosic and herbaceous biomasses.

Table 1. Elemental analysis $\left(\mathrm{db}, \%_{\mathrm{w} / \mathrm{w}}\right)$ of jatropha wood in comparison with other biomasses (figures in parentheses are standard deviations).

\begin{tabular}{|c|c|c|c|c|c|c|c|}
\hline Biomass & C & $\mathbf{H}$ & $\mathbf{N}$ & $\mathbf{O}$ & $\mathbf{C} / \mathbf{N}$ & $\mathrm{H} / \mathrm{C}$ & $\mathrm{O} / \mathrm{C}$ \\
\hline Jatropha prunings & $\begin{array}{c}39.42 \\
( \pm 1.10)\end{array}$ & $\begin{array}{c}9.83 \\
( \pm 1.65)\end{array}$ & $\begin{array}{c}3.53 \\
( \pm 0.04)\end{array}$ & 41.14 & 13.02 & 2.97 & 0.78 \\
\hline Olive tree prunings & $\begin{array}{c}48.67 \\
( \pm 1.31)\end{array}$ & $\begin{array}{c}6.91 \\
( \pm 0.12)\end{array}$ & $\begin{array}{c}0.76 \\
( \pm 0.04)\end{array}$ & 41.01 & 74.68 & 1.69 & 0.63 \\
\hline Vine prunings & $\begin{array}{c}50.56 \\
( \pm 1.41)\end{array}$ & $\begin{array}{c}6.63 \\
( \pm 0.25)\end{array}$ & $\begin{array}{c}0.63 \\
( \pm 0.06)\end{array}$ & 39.65 & 93.59 & 1.56 & 0.59 \\
\hline Giant reed (stem and leaves) & $\begin{array}{c}44.72 \\
( \pm 1.23)\end{array}$ & $\begin{array}{c}6.43 \\
( \pm 0.22)\end{array}$ & $\begin{array}{c}0.62 \\
( \pm 0.07)\end{array}$ & 41.27 & 84.12 & 1.71 & 0.69 \\
\hline Cardoon (stem and leaves) ${ }^{a}$ & 40.6 & 5.50 & 0.90 & 45.00 & 52.61 & 1.61 & 0.83 \\
\hline
\end{tabular}

Elemental analysis (CHNS) was carried out to investigate carbon, hydrogen, nitrogen, and sulfur content in Jatropha wood (Table 1). Carbon, hydrogen, and oxygen are the main constituents of wood biomass and their relative concentrations vary with the type of wood. Carbon is the component which contributes most to raising the HHV and is correlated to the presence of cellulose, hemicellulose, and lignin [28]. The average carbon content of Jatropha wood provides results of about $40 \%$, close to the values of herbaceous crops.

The content of nitrogen $(\mathrm{N})$ in common biofuels is quite low with values normally less than $1 \%$, and is particularly high in cereals and oil-seeds where it can reach $5 \%$ [28]. In jatropha wood, the nitrogen content was very high (3.53\%), probably due to a higher concentration of protein [36]. In the jatropha samples no traces of sulfur at values higher than $500 \mathrm{ppm}$ were found (the detection limit of the instrument). This result is very important because sulfur generally is correlated with corrosion and pollution emissions. 
For all biomasses reported in Table 1, sulfur content (S) was $<0.05 \%$ and, hence, it was considered negligible, as only Cynara cardunculus L. and Arundo donax L. resulted in values up to $0.1 \%$ [35] and $0.18 \%$, respectively.

As reported in Reference [37], for thermochemical processes (combustion, pyrolysis, gasification), a biomass with a high $\mathrm{C} / \mathrm{N}$ ratio $(>30)$, high lignin content, and low humidity $(<30 \%)$ is preferable, while for biological processes (alcoholic fermentation, anaerobic digestion) a biomass with a low $\mathrm{C} / \mathrm{N}$ ratio $(<30)$, low lignin content, and higher humidity $(>30 \%)$ is more appreciated. As can be seen from Table 1, the wood species (olive and vine) have a $\mathrm{C} / \mathrm{N}$ ratio higher than 30 . The wood moisture may depend on the characteristics of the type of wood, the cutting period, the storage time, and the weather conditions. Arundo donax, L. has a C/N ratio in the range of values of vines and olive (in fact, $\mathrm{N}$ is about 0.6), although the higher moisture content found at harvest requires an intermediate storage aimed at reducing moisture. As reported by Reference [35], cardoon has a lower $\mathrm{C} / \mathrm{N}$ ratio $(>30,52.61)$ than the other feedstocks analyzed, and a very low moisture content (Table 2). Samples of jatropha wood were not subjected to drying pretreatment with a very high moisture content and a $\mathrm{C} / \mathrm{N}$ ratio of 13.02 (Table 1). Based on these two parameters (M.C. and C/N), jatropha wood seems to be unsuitable for direct use in thermochemical processes by itself. Furthermore, the $\mathrm{N}$ content is more than 3.5 times higher than that of the other species analyzed.

Moisture affects the physical, mechanical, and technological characteristics of the wood and has a negative impact on both the cleaning and energy efficiency of the boilers (e.g., acid condensation, fouling, sludging). In fact, it decreases the HHV of the biomass, due to the thermal energy wasted to evaporate the water, which is estimated at $2.4 \mathrm{MJ} \cdot \mathrm{kg}^{-1}$. To reduce the moisture content of biomass, prunings may be left in the field or stored at the edge of the field until they reach the moisture required for subsequent processing.

In the case of jatropha wood, the LHV is lower than that of other tree species (Table 2). In woody biomass calorific values do not vary much and are between 18 and $19 \mathrm{MJ} \cdot \mathrm{kg}^{-1}$, as confirmed by the results of olive tree and vine prunings. In particular, it is possible to observe that the lower heating value of jatropha wood resulted in the range from 14 to $18 \mathrm{MJ} \cdot \mathrm{kg}^{-1}$, corresponding firstly to the value of herbaceous biomass, such as giant reeds, and the latter to lignocellulosic biomass, such as olive and vine prunings. It is well known that lignin is the component that has a greater effect on raising the HHV compared to other compounds in the wood [38-40]. In fact, lignin, cellulose, and hemicellulose have an $\mathrm{HHV}$ of $26.5 \mathrm{MJ} \cdot \mathrm{kg}^{-1}, 17.5 \mathrm{MJ} \cdot \mathrm{kg}^{-1}$, and $16 \mathrm{MJ} \cdot \mathrm{kg}^{-1}$, respectively. Yamamura et al. (2012) observed a lignin content in jatropha stems of six-month-old plants and in the secondary xylem of one-year-old stems of $15.90 \%$ and $19.88 \%$, respectively [41], while another study [42] found higher lignin content $(24.11 \%)$, which might be due to a different maturity of the stems, different growth conditions, or genetic background [41]. However, the values were always lower than the lignin content in vine prunings (26.68-30.18\%) [43] and in olive prunings (27.64\%) [44].

As suggested by [45], the classification method based on the van Krevelen diagram (plot of H/C versus $\mathrm{O} / \mathrm{C}$ atomic ratios) has been applied to the feedstocks analyzed (Figure 2). This method is often used to describe the maturity, decomposition rate, and combustion behavior of fossil chars and coal [46], but also to predict biomass properties, such as the higher heating value, and potentially in predicting lignin, and other similar quantities for biomass [47]. The biomass feedstocks that fall within clusters in the van Krevelen diagram will have similar properties, regardless of their category (waste, wood, etc.). With the atomic O:C and $\mathrm{H}: \mathrm{C}$ ratios it is possible to observe the influence on the calorific value of solid fuels [48]. In fact, the atomic O:C and $\mathrm{H}: \mathrm{C}$ ratios of the biomass analyzed showed that the higher proportion of oxygen and hydrogen, compared with carbon, reduces the energy value due to the lower energy contained in carbon-oxygen and carbon-hydrogen bonds, than in carbon-carbon bonds [48].

$\mathrm{C}$ and $\mathrm{H}$ become oxidized during combustion by exothermic reactions (formation of $\mathrm{CO}_{2}$ and $\mathrm{H}_{2} \mathrm{O}$ ) and, therefore, the influence the gross calorific value of the fuel [49]. The C content in woody biomass is higher than in herbaceous biomass fuels, explaining the slightly higher gross calorific value 
of woody biomass (Figure 2). Furthermore, jatropha wood has a higher H:C ratio, indicating a major predisposition to microbial degradation [46].

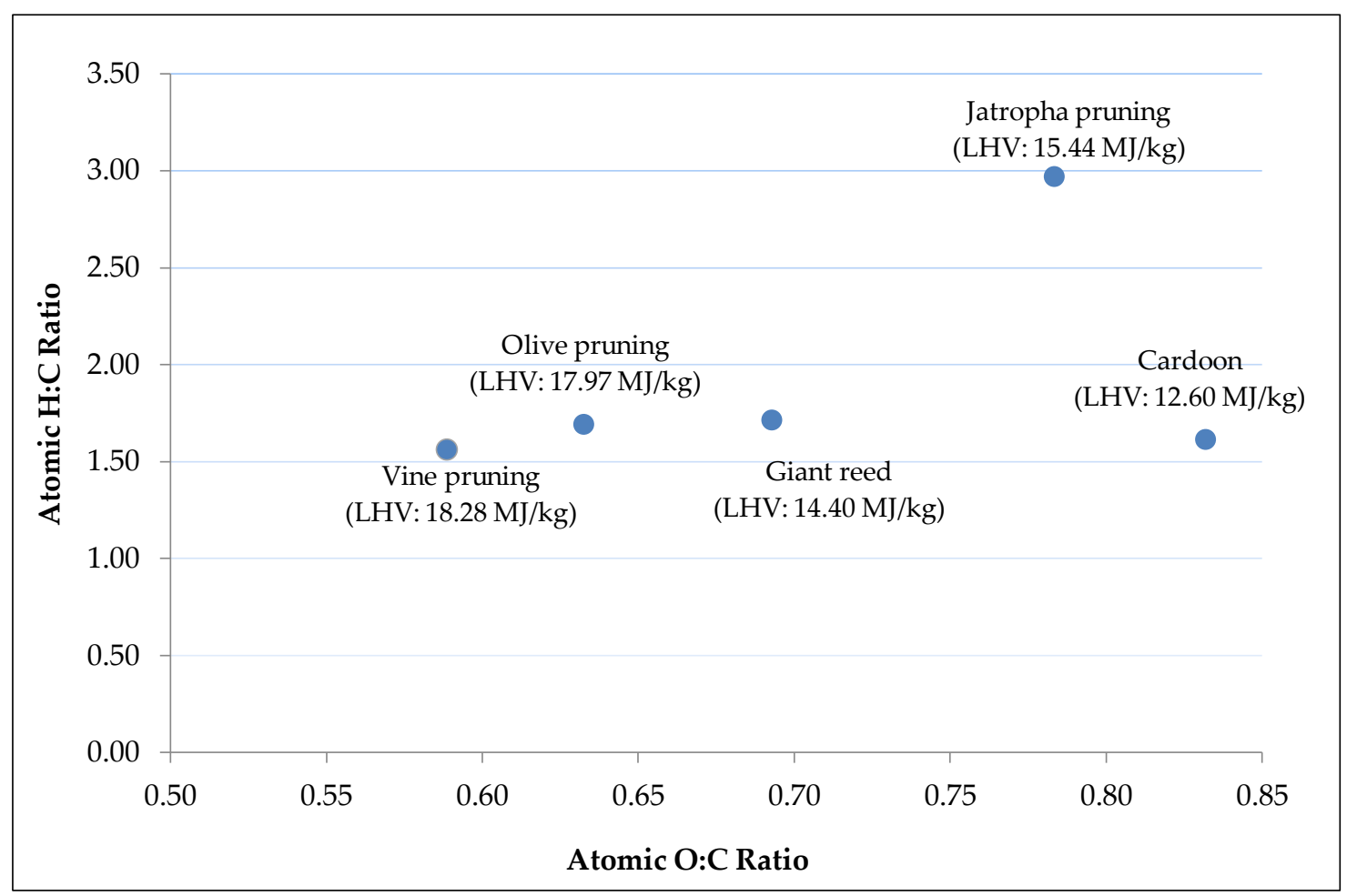

Figure 2. Van Krevelen diagram-hydrogen:carbon (hydrogen index) as a function of the oxygen:carbon (oxygen index) atomic ratios of the biomass analysed.

However, it should be noted that the composition of the biomass can vary depending on a number of factors, such as the time of harvest, soil type, geographical location, and a considerable variability of composition can be observed even in the same stem and between different trees [50].

High ash content is another characteristic that negatively affects the biomass energy content [51]. Ash is an inorganic material that remains after the combustion of the fuel. Increasing the amount of ash adversely affects the calorific value because it represents the fraction of the wood that remains unburned [52] and also affects boiler performance. Finally, it also affects the boiler management costs because a high content of ash means more material to be disposed of as special waste [53].

Table 2. Physical characteristics of jatropha wood in comparison with other types of biomass (figures in parentheses are standard deviations).

\begin{tabular}{|c|c|c|c|c|c|c|c|}
\hline Biomass & $\begin{array}{l}\text { M.C. }{ }^{a} \\
\left(\%_{w / w}\right)\end{array}$ & $\begin{array}{c}\text { HHV } \\
\left(\mathrm{MJ} \cdot \mathrm{kg}_{\mathrm{db}}-1\right)\end{array}$ & $\begin{array}{c}\mathrm{LHV}^{\mathrm{b}} \\
\left(\mathrm{MJ} \cdot \mathrm{kg}_{\mathrm{db}}{ }^{-1}\right)\end{array}$ & $\begin{array}{c}\text { Ash } \\
\left(\%_{w / w}\right)\end{array}$ & $\begin{array}{l}\text { Hemicellulose } \\
\left(\%_{w / w}\right)\end{array}$ & $\begin{array}{c}\text { Cellulose } \\
\left(\%_{w / w}\right)\end{array}$ & $\begin{array}{l}\text { Lignin } \\
\left(\%_{w / w}\right)\end{array}$ \\
\hline Jatropha prunings & 78.5 & $\begin{array}{c}17.46 \\
( \pm 0.14)\end{array}$ & 15.44 & $\begin{array}{c}6.08 \\
( \pm 0.24)\end{array}$ & n.a. & $42.99^{c}$ & $15.90^{\mathrm{d}}$ \\
\hline Olive tree prunings & 33.7 & $\begin{array}{c}19.39 \\
( \pm 0.17)\end{array}$ & 17.97 & $\begin{array}{c}2.65 \\
( \pm 0.49)\end{array}$ & $21.96^{\mathrm{e}}$ & $38.81^{\mathrm{e}}$ & $27.64^{\mathrm{e}}$ \\
\hline Vine prunings & 37.5 & $\begin{array}{c}19.65 \\
( \pm 0.21)\end{array}$ & 18.28 & $\begin{array}{c}2.53 \\
( \pm 1.04)\end{array}$ & $32.79^{\mathrm{f}}$ & $38.20^{\mathrm{f}}$ & $26.68^{f}$ \\
\hline Giant reed (stem and leaves) & 36.1 & $\begin{array}{c}15.72 \\
( \pm 0.86)\end{array}$ & 14.40 & $\begin{array}{c}6.78 \\
( \pm 1.15)\end{array}$ & $28.50 \mathrm{~g}$ & $36.77^{g}$ & $21.0 \mathrm{~g}$ \\
\hline Cardoon (stem and leaves) ${ }^{\mathrm{h}}$ & 8.2 & 13.70 & 12.60 & 7.20 & 16.90 & 53.30 & 19.70 \\
\hline
\end{tabular}

a_-Moisture content of fresh matter measured during the harvesting; ${ }^{\mathrm{b}}$ - Calculated from HHV and hydrogen content according to [29]; ${ }^{\mathrm{c}}$-Source: [54]; ${ }^{\mathrm{d}}$-Source: [41]; ${ }^{\mathrm{e}}$-Source: [44]; ${ }^{\mathrm{f}}$-Source: [43]; ${ }^{\mathrm{g}}$-Source: [55];

h_Source: [35]. 
Jatropha branch combustion data (Table 2) showed an average ash content of $6.1 \%$. This value is greater than those of olive and vine prunings that showed an ash content lower than $3 \%$ and, in general, if compared with the values obtainable from woody biomass usually used for the production of energy, ranged from $0.7 \%$ to $1.4 \%$ [56]. On the contrary, the ash content of jatropha wood is slightly less than the values of Arundo donax and cardoon that correspond to $6.8 \%$ and $7.2 \%$, and in general it is compatible with values of herbaceous crops or residues used for energy purpose and that are within a range from $2.2 \%$ to $8.2 \%$ [57].

However, the significant quantities of potassium and phosphorus contained in ash should be considered [58]. Ash could be reused as fertilizer to replenish the soil with minerals that are withdrawn from the plant during growth; in fact, there are already experimental projects and research for ash reuse in open fields [59].

During the combustion process, the ash is subjected to chemical and physical modifications that cause initial deformation until the ash particles have completely melted. The temperature of the fusibility of ash is a very important parameter to investigate because fuel with a low ash melting point increases the risk of slag and fouling formation and corrosion of the boiler, as well as deposits of melted ash at the heat exchangers. Slagging and fouling are two problems caused by the deposit of ash on the internal boiler surfaces.

The "slugging" indicates an accumulation of molten ash particles on the internal surfaces of the boiler, while the "fouling" indicates inorganic vapors that condense on the colder surface of the boiler. These phenomena can significantly reduce the efficiency of the heat exchangers. They are both due to ash with a low melting point. The melting point of the ash is influenced by the type of minerals that are in it; elements such as calcium and magnesium increase the melting temperature while potassium and sodium make it lower. Woody biomass with a high ash melting point is, thus, essential to increase the productivity of the system and to reduce maintenance costs. The melting temperatures of the ashes were not observed in the jatropha samples because they were higher than $1600{ }^{\circ} \mathrm{C}$ (the maximum value reachable by the instrument) (Figure 3). This aspect makes the jatropha wood suitable for the boiler because it preserves the boiler by the phenomena of slagging and fouling already described above. Tests on herbaceous biomass, such as reed canary grass, show a melting temperature in all phases over $1200{ }^{\circ} \mathrm{C}$ up to about $1250{ }^{\circ} \mathrm{C}$, while for woody biomasses, such as birch and poplar, are from $1400{ }^{\circ} \mathrm{C}$ up to about $1500^{\circ} \mathrm{C}[60,61]$. In a recent study [62], the ash melting point of Arundo donax, L. was $896^{\circ} \mathrm{C}$. From these results, it is possible to observe that the ash melting point of jatropha is higher than that of woody biomass that are normally used in biomass combustion plants.

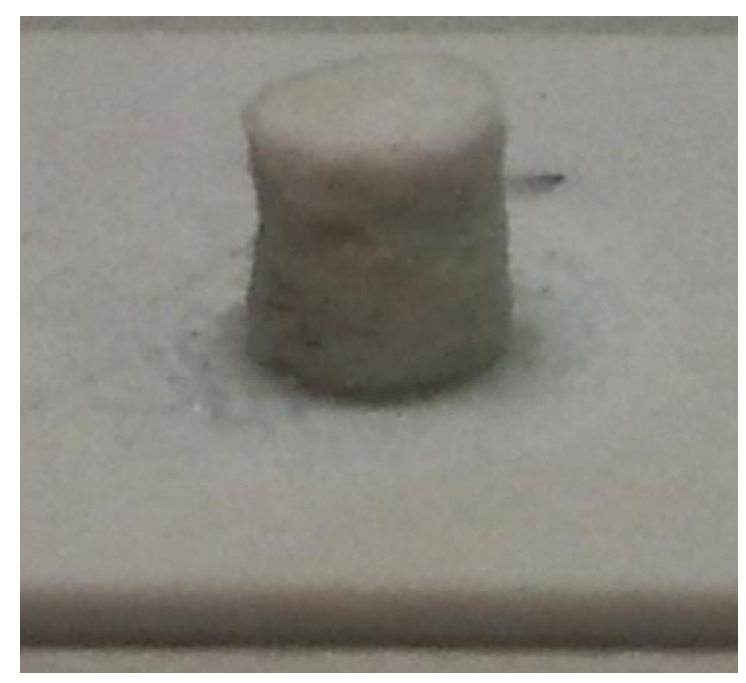

Figure 3. Ash sample of jatropha wood after the test $\left(1600^{\circ} \mathrm{C}\right)$. 


\section{Discussion}

One of the primary advantages of biomass is that it can be burnt directly to produce electricity without any type of chemical processing, or to produce heat in industrial plants and houses using boilers [63]. Jatropha prunings are a lignocellulosic biomass that could represent an important source for renewable energy production through thermochemical process, such as gasification for syngas and biochar and combustion for heat and power generation [64,65]. An important aspect concerns the environmental impact linked to the use of biomass in combustion plants, as flue gases from woody biomass combustion contain different compounds, such as greenhouse gases $\left(\mathrm{CO}_{2}, \mathrm{CH}_{4}\right.$, and $\left.\mathrm{N}_{2} \mathrm{O}\right)$ and air pollutants $\left(\mathrm{CO}, \mathrm{NO}_{\mathrm{x}}, \mathrm{SO}_{\mathrm{x}}\right.$, VOCs, and $\left.\mathrm{PM}\right)$. Values of GHG and pollutants depend on the type and characteristics of biomass, and on the operating condition of plants, hence, the thermodynamic condition of the process, and on the presence of systems for gas cleanup [65].

The main source of greenhouse gas emissions from a boiler is carbon dioxide $\left(\mathrm{CO}_{2}\right)$ produced from the combustion [63]. Nevertheless, the use of this agricultural residue for energy production has environmental advantages. In fact, the use of plants or their residues for biofuel helps to maintain a constant level of carbon dioxide because plants fix $\mathrm{CO}_{2}$ during growth [5]. For this reason, the use of biomass in combustion plants is characterized by a zero $\mathrm{CO}_{2}$ emission balance if referred to the life cycle of the crop, while the thermal use of biomass is considered a solution to limit the greenhouse gas effect [5] and to achieve energy independence while generating jobs [66].

If open-air burning is used as a pruning disposal method, the annual potential yield of jatropha

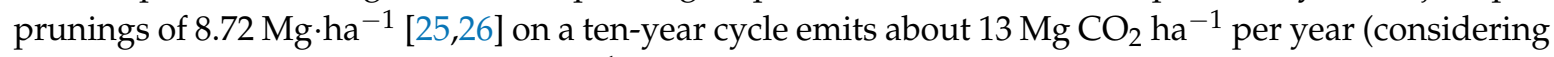
an average emission of $1550 \mathrm{~g} \mathrm{CO}_{2} \mathrm{~kg}^{-1}$ of dry matter burned [67]). On the contrary, the same amount of woody biomass could provide $134 \mathrm{GJ} \cdot \mathrm{ha}^{-1}$ per year (considering a jatropha pruning LHV of $15.44 \mathrm{MJ} \cdot \mathrm{kg}_{\mathrm{dm}}{ }^{-1}$ ). This energy amount is equivalent to 3.2 toe ha ${ }^{-1} \cdot \mathrm{y}^{-1}$ ( 1 toe $=0.024 \mathrm{GJ}$ [68]), or 23.5 boe ( 1 boe $=7.33$ toe [68]). From a rough estimate, it can, therefore, be deduced that the use of jatropha wood to produce energy would avoid an average annual emission of $10.1 \mathrm{Mg} \mathrm{CO}_{2}$ ha $^{-1}$ per year from fossil fuels (considering an emission of 0.43 metric tons $\mathrm{CO}_{2}$ boe $^{-1}$ [69]).

Obviously, an additional amount of $\mathrm{CO}_{2}$ emission must be taken into account considering the biomass collection, transport, and transformation, such as chipping [51]. Furthermore, the high nitrogen content observed during the analysis could mean a major release of $\mathrm{NO}_{\mathrm{x}}$ in the atmosphere during combustion. For this reason more research is necessary to assess the environmental convenience of the jatropha pruning supply chain, for the production of energy. The analysis carried out showed that the ash content and high moisture content are critical. From the results obtained so far, and in accordance with Reference [23], it is important to highlight that the high moisture and ash contents, and the low LHV, of jatropha wood make it unsuitable as solid fuel for combustion. Even in the form of charcoal, the use of the wood would not be suitable because the transformation process would be too expensive.

Although logistics aimed at reducing the moisture content (e.g., the on-field drying of the product in the field), using the ash as fertilizer could mitigate the technical problems and economic costs linked to these two parameters (moisture and ash content).

Furthermore, on the positive side, the ash melting point resulted in being higher than those of lignocellulosic biomass, such as poplar, which means that the use of jatropha wood in biomass combustion plants would not cause technical problems linked to slag and fouling formation.

In order to increase the amount of energy per unit of volume, it could be possible to envisage the energy concentration of the material by means of pelletizing. The HHV of wood pellets can vary between $17.6 \mathrm{MJ} \cdot \mathrm{kg}^{-1}$ and $20.8 \mathrm{MJ} \cdot \mathrm{kg}^{-1}$, and in the case of tropical wood pellets, the HHV is, on average, $19.9 \mathrm{MJ} \cdot \mathrm{kg}^{-1}$ [70]. The mobile pelletizing machine already proposed by [71] for the energetic use of agricultural by-products (agri-pellet) could be a scenario to evaluate the jatropha residues of future studies. This scenario could also include the production of residual biomass mixture pellets in order to obtain a product with a better combustion behavior than the individual elements of the product. 
By pelletizing, it is possible to obtain an increase in density of the pelletized product, even up to 10-15 times its original matrix. This would significantly improve the handling of the biomass, the energy efficiency and, therefore, reduce the costs [71]. The shipping costs are lowered as a consequence of the lower moisture content of the pellets (8-13\%). The combustion of the pelletized residue will be significantly better from an energy and environmental point of view when compared to the original biomass. These results have also been confirmed by Reference [72] where the investment into the manufacture of pellets made of wood residues is justified. However, a more specific research would be necessary in order to assess the feasibility and sustainability of the entire supply chain of residual biomass mixture pellets that also include jatropha wood from tropical or sub-tropical areas.

\section{Conclusions}

Among the various conversion technologies, combustion is the most common and developed method of converting biomass fuels to energy. This study aimed to evaluate the potential utilization of jatropha prunings for energy production. Physicochemical characterization was carried out in order to verify the suitability of its wood as biofuel for industrial boilers. According to the chemical and physical analysis carried out on the pruning residues of Jatropha curcas, L., and in accordance with other studies, it is not suitable as a solid biofuel for combustion. In fact, the high $\mathrm{C} / \mathrm{N}$ ratio makes the wood more suitable for biological transformation. In addition, the high moisture content of wood makes the logistics chain more complex and less cost-efficient.

However, the woody biomass analyzed showed characteristics similar to that of herbaceous crops already used as fuel, and the pelletizing process could reduce the moisture content and increase the HHV of jatropha wood, reducing the costs related to storage. Furthermore, the high ash melting point of jatropha wood represents a technical feature of great importance, which could improve the properties of an agri-pellet obtained from a mix of various agricultural waste. In fact, agricultural residues are an important source of biomass which can often present problems during combustion due to the low melting point of the ashes (e.g., cereal straw).

Thus, future studies should analyze the combustion behavior of various biomass mixtures based on agricultural residues with jatropha wood to evaluate the changes in performance during combustion. In this prospective, jatropha prunings may represent a good resource of biomass for energy. Furthermore, it could provide extra income for the farmers and have good effects for the environment due to the avoided emissions of $\mathrm{CO}_{2}$ from fossil fuels. However, due to the high nitrogen content of jatropha wood, another line of research should measure the amount of $\mathrm{NO}_{\mathrm{x}}$ produced during the combustion phase, in order to assess the environmental sustainability of the fuel.

Finally, further studies should evaluate the economic sustainability of the entire supply chain and the marketability of such agri-pellest (that includes part of jatropha wood from tropical or sub-tropical areas) in Western countries where the demand for pellets is increasing, and it cannot be expected (at least in the near future) that the offer could exceed the demand.

Author Contributions: This study is a result of a full collaboration of all the authors. A.S. carried out the general coordination of the study with the scientific guidance of L.P. A.S. wrote Section 1 (Introduction) and Section 5 (Conclusion). A.S., L.L., and M.C. wrote Section 2 (Materials and Methods). A.S. wrote Sections 3 and 4 (Results and Discussion) with the support of L.L. F.G. and L.L. provided the interpretation of the data. M.C. carried out all the laboratory analysis. L.P. and F.G. performed the final revision of the study and the approval of the version to be published.

Acknowledgments: This work was funded by the Project SUSCACE (SUpporto Scientifico alla Conversione Agricola alle Colture Energetiche), MIPAAF, D.M. 2419 of 20/02/2008. We would like to thank Giuseppe Toscano, research group leader of the Biomass Group of the D3A Department of the Polytechnic University of Marche (Italy) for the cross-validation of the results of the ash melting point of jatropha wood. Our very special gratitude goes out to Abdelkader Outzourhit, Ahmed Ouhammou, and Rachid Ait Babahmad of the Université Cadi Ayyad of Marrakesh (Morocco) for their local support and kind welcome. Thanks also go to Rafaela Bellacima and Federico Blesi for their early laboratory analysis results. 
Conflicts of Interest: The authors declare no conflict of interest. The founding sponsors had no role in the design of the study; in the collection, analyses, or interpretation of data; in the writing of the manuscript; or in the decision to publish the results.

$\begin{array}{ll}\text { Abbreviations } \\ \text { AC } & \text { Ash Content } \\ \text { boe } & \text { Barrel of oil equivalent } \\ \text { CHNS } & \text { Carbon, hydrogen, nitrogen and sulphur elemental analysis } \\ \text { db } & \text { Dry basis } \\ \text { GHG } & \text { Greenhouse Gas } \\ \text { HHV } & \text { Higher Heating Value } \\ \text { LAS-ER-B } & \text { Laboratory for Experimental Activities on Renewable Energy from Biomass } \\ \text { LHV } & \text { Lower Heating Value } \\ \text { Mar } & \text { Moisture content as received } \\ \text { PM } & \text { Particulate Matter } \\ \text { toe } & \text { Tonnes of oil equivalent } \\ \text { VOCs } & \text { Volatile Organic Compounds }\end{array}$

\section{References}

1. Vasudevan, P.; Sharma, S.; Kumar, A. Liquid fuel from biomass: An overview. J. Sci. Ind. Res. (India) 2005, 64, 822-831.

2. Garcì-Galindo, D.; Lopez, E.; Gòmez, M.; Sebastián, F.; Gebresenbet, G.; Jirjis, R.; Kern, J.; Germer, S.; Pari, L.; Suardi, A.; et al. Europruning project: Summary of final results. In Proceedings of the 24th European Biomass Conference and Exhibition, Amsterdam, The Netherlands, 6-9 June 2016; pp. 89-102.

3. Achten, W.M.J.; Verchot, L.; Franken, Y.J.; Mathijs, E.; Singh, V.P.; Aerts, R.; Muys, B. Jatropha bio-diesel production and use. Biomass Bioenergy 2008, 32, 1063-1084. [CrossRef]

4. Pari, L.; Suardi, A.; Santangelo, E.; García-Galindo, D.; Scarfone, A.; Alfano, V. Current and innovative technologies for pruning harvesting: A review. Biomass Bioenergy 2017, 107, 398-410. [CrossRef]

5. Gonçalves, C.; Evtyugina, M.; Alves, C.; Monteiro, C.; Pio, C.; Tomé, M. Organic particulate emissions from field burning of garden and agriculture residues. Atmos. Res. 2011, 101, 666-680. [CrossRef]

6. Keshtkar, H.; Ashbaugh, L.L. Size distribution of polycyclic aromatic hydrocarbon particulate emission factors from agricultural burning. Atmos. Environ. 2007, 41, 2729-2739. [CrossRef]

7. Magagnotti, N.; Nati, C.; Spinelli, R.; Vieri, M. Technical protocol for the utilization of pruning residues from vineyards and olive groves. In The Forest-Wood-Energy Chain: Results from the International Project Woodland Energy; ARSIA di Regione Toscana: Florence, Italy, 2009.

8. Spinelli, R.; Lombardini, C.; Pari, L.; Sadauskiene, L. An alternative to field burning of pruning residues in mountain vineyards. Ecol. Eng. 2014, 70, 212-216. [CrossRef]

9. Toscano, G.; Duca, D.; Foppa Pedretti, E.; Pizzi, A.; Rossini, G.; Mengarelli, C.; Mancini, M. Investigation of woodchip quality: Relationship between the most important chemical and physical parameters. Energy 2016, 106, 38-44. [CrossRef]

10. Perea-Moreno, A.-J.; Perea-Moreno, M.-Á.; Hernandez-Escobedo, Q.; Manzano-Agugliaro, F. Towards forest sustainability in Mediterranean countries using biomass as fuel for heating. J. Clean. Prod. 2017, 156, 624-634. [CrossRef]

11. Toscano, G.; Riva, G.; Duca, D.; Pedretti, E.F.; Corinaldesi, F.; Rossini, G. Analysis of the characteristics of the residues of the wine production chain finalized to their industrial and energy recovery. Biomass Bioenergy 2013, 55, 260-267. [CrossRef]

12. Thornley, P.; Gilbert, P.; Shackley, S.; Hammond, J. Maximizing the greenhouse gas reductions from biomass: The role of life cycle assessment. Biomass Bioenergy 2015, 81, 35-43. [CrossRef]

13. Searle, S.; Malins, C. National Case Studies on Potential Waste and Residue Availability for Cellulosic Biofuel Production in the EU; The International Council on Clean Transportation: Washington, DC, USA, 2015.

14. Makkar, H.P.S.; Francis, G.; Becker, K. Protein concentrate from Jatropha curcas screw-pressed seed cake and toxic and antinutritional factors in protein concentrate. J. Sci. Food Agric. 2008, 88, 1542-1548. [CrossRef] 
15. Devappa, R.K.; Makkar, H.P.S.; Becker, K. Jatropha toxicity-A review. J. Toxicol. Environ. Health Part B Crit. Rev. 2010, 13, 476-507. [CrossRef] [PubMed]

16. Sricharoenchaikul, V.; Marukatat, C.; Atong, D. Fuel production from physic nut (Jatropha curcas L.) waste by fixed-bed pyrolysis process. Thail. J. 2007, 2550, 1-6.

17. Openshaw, K. A review of Jatropha curcas: An oil plant of unfulfilled promise. Biomass Bioenergy 2000, 19, 1-15. [CrossRef]

18. Sabandar, C.W.; Ahmat, N.; Jafar, M.F.; Sahidin, I. Medical property, phytochemistry and pharmacology of several Jatropha spesies (Euphorbiaceae). Phytochemsitry 2013, 85, 7-12. [CrossRef] [PubMed]

19. Contran, N.; Chessa, L.; Lubino, M.; Bellavite, D.; Roggero, P.P.; Enne, G. State-of-the-art of the Jatropha curcas productive chain: From sowing to biodiesel and by-products. Ind. Crops Prod. 2013, 42, 202-215. [CrossRef]

20. Francis, G.; Oliver, J.; Sujatha, M. Non-toxic jatropha plants as a potential multipurpose multi-use oilseed crop. Ind. Crops Prod. 2013, 42, 397-401. [CrossRef]

21. Phasukarratchai, N.; Tontayakom, V.; Tongcumpou, C. Reduction of phorbol esters in Jatropha curcas L. pressed meal by surfactant solutions extraction. Biomass Bioenergy 2012, 45, 48-56. [CrossRef]

22. Kumar, A.; Sharma, S. An evaluation of multipurpose oil seed crop for industrial uses (Jatropha curcas L.): A review. Ind. Crops Prod. 2008, 28, 1-10. [CrossRef]

23. Benge, M. Assessment of the Potential of Jatropha curcas, (Biodiesel Tree,) for Energy Production and Other Uses in Developing Countries. Available online: https://pdfs.semanticscholar.org/ 03c3/fc89d37e5a99c1684fa8dbe4e26611dba92e.pdf?_ga=2.147401264.662696569.1521042215-331838524. 1521042215 (accessed on 10 May 2018).

24. Gour, V.K. Production practices including post-harvest management of Jatropha curcas. In Proceedings of the Biodiesel Conference toward Energy Independence-Focus of Jatropha, Hyderabad, India, 9-10 June 2006; pp. 223-251.

25. Sotolongo, J.A.; Soler, P.B.; Díaz, A.; Montes de Oca, S.; del Vallel, Y.; Pavón, S.G.; Vigouroux, R.Z. Jatropha curcas L. as a source for the production of biodiesel: A Cuban experience. In Proceedings of the 15th European Biomass Conference and Exhibition, Berlin, Germany, 7-11 May 2007; pp. 2631-2633.

26. Jingura, R.M.; Musademba, D.; Rutendo, M. An evaluation of utility of Jatropha curcas L. as a source of multiple energy carriers. Int. J. Eng. Sci. Technol. 2010, 2, 115-122. [CrossRef]

27. ISO 18134-1:2015. Solid Biofuels-Determination of Moisture Content-Oven Dry Method-Part 1: Total Moisture—Reference Method; International Organization for Standardization: Geneva, Switzerland, 2015; p. 5.

28. Todaro, L.; Scopa, A.; As, D.F.; Spartium, L.; Rubus, W.; Onopordum, L.; For, L.Q. Caratterizzazione energetica di specie arboree e arbustive di aree collinari e montane della Basilicata (Energy characterisation of tree and shrub species in hilly and mountainous areas of Basilicata region). Forest 2007, 4, 42-50. [CrossRef]

29. ISO 18125:2017. Solid Biofuels—Determination of Calorific Value; International Organization for Standardization: Geneva, Switzerland, 2018; p. 56.

30. ISO 18122:2015. Solid Biofuels—Determination of Ash Content; International Organization for Standardization: Geneva, Switzerland, 2015; p. 6.

31. CEN/TS 15370-1:2006. Solid Biofuels-Method for the Determination of Ash Melting Behaviour-Part 1: Characteristic Temperatures Method; European Committee for Standardization: Brussels, Belgium, 2006; p. 11.

32. ISO 16948:2015. Solid Biofuels-Determination of Total Content of Carbon, Hydrogen and Nitrogen; International Organization for Standardization: Geneva, Switzerland, 2015; p. 9.

33. Conte, P.; Schmidt, H.-P.; Cimò, G. Research and application of biochar in Europe. Agric. Environ. Appl. Biochar Adv. Barriers 2016, 409-422. [CrossRef]

34. Gallucci, F.; Longo, L.; Pari, L.; Salerno, M.; Carnevale, M.; Paolini, V.; Colantoni, A. Assessment of syngas produced by gasification with air of vine prunings through a downdraft reactor. In Proceedings of the 25th European Biomass Conference and Exhibition, Stockholm, Sweden, 12-15 June 2017; pp. 803-807.

35. Grammelis, P.; Malliopoulou, A.; Basinas, P.; Danalatos, N.G. Cultivation and characterization of Cynara cardunculus for solid biofuels production in the mediterranean region. Int. J. Mol. Sci. 2008, 9, 1241-1258. [CrossRef] [PubMed]

36. Vidrich, V. Il Legno ed I Suoi Impieghi Chimici; Eda-Gricole: Bologna, Italy, 1988; ISBN 8820626179.

37. Bonari, E.; Maracchi, G. Le Biomasse Lignocellulosiche (Lignocellulosic Biomass); Firenze Un.: Florenze, Italy, 2016; ISBN 8866559849. 
38. Callejón-Ferre, A.J.; Carreño-Sánchez, J.; Suárez-Medina, F.J.; Pérez-Alonso, J.; Velázquez-Martí, B. Prediction models for higher heating value based on the structural analysis of the biomass of plant remains from the greenhouses of Almería (Spain). Fuel 2014, 116, 377-387. [CrossRef]

39. Álvarez, A.; Pizarro, C.; García, R.; Bueno, J.L. Spanish biofuels heating value estimation based on structural analysis. Ind. Crops Prod. 2015, 77, 983-991. [CrossRef]

40. Sheng, C.; Azevedo, J.L.T. Estimating the higher heating value of biomass fuels from basic analysis data. Biomass Bioenergy 2005, 28, 499-507. [CrossRef]

41. Yamamura, M.; Akashi, K.; Yokota, A.; Hattori, T.; Suzuki, S.; Shibata, D.; Umezawa, T. Characterization of Jatropha curcas lignins. Plant Biotechnol. 2012, 29, 179-183. [CrossRef]

42. Vaithanomsat, P.; Apiwatanapiwat, W. Feasibility study on vanillin production from Jatropha curcas stem using steam explosion as a pretreatment. Int. J. Chem. Biol. Eng. 2009, 3, 839-842.

43. Nasser, R.A.; Salem, M.Z.M.; Al-Mefarrej, H.A.; Abdel-Aal, M.A.; Soliman, S.S. Fuel characteristics of vine prunings (Vitis vinifera L.) as a potential source for energy production. BioResources 2014, 9, 482-496. [CrossRef]

44. Garcia-Maraver, A.; Salvachúa, D.; Martínez, M.J.; Diaz, L.F.; Zamorano, M. Analysis of the relation between the cellulose, hemicellulose and lignin content and the thermal behavior of residual biomass from olive trees. Waste Manag. 2013, 33, 2245-2249. [CrossRef] [PubMed]

45. Chen, Y.; Charpenay, S.; Jensen, A.; Wójtowicz, M.A.; Serio, M.A. Modeling of biomass pyrolysis kinetics. In Proceedings of the 27th Symposium (International) on Combustion, Boulder, CO, USA, 2-7 August 1998; Elsevier: New York, NY, USA, 1998; Volume 27, pp. 1327-1334.

46. Zambon, I.; Colosimo, F.; Monarca, D.; Cecchini, M.; Gallucci, F.; Proto, A.R.; Lord, R.; Colantoni, A. An innovative agro-forestry supply chain for residual biomass: Physicochemical characterisation of biochar from olive and hazelnut pellets. Energies 2016, 9, 526. [CrossRef]

47. Jones, J.M.; Lea-Langton, A.R.; Ma, L.; Pourkashanian, M.; Williams, A. Combustion of solid biomass: Classification of fuels. In Pollutants Generated by the Combustion of Solid Biomass Fuels; Springer: New York, NY, USA, 2014; pp. 9-24.

48. McKendry, P. Energy production from biomass (Part 1): Overview of biomass. Rev. Issue 2002, 83, 37-46. [CrossRef]

49. Obernberger, I.; Thek, G. Physical characterisation and chemical composition of densified biomass fuels with regard to their combustion behaviour. Biomass Bioenergy 2004, 27, 653-669. [CrossRef]

50. Jones, J.M.; Lea-Langton, A.R.; Ma, L.; Pourkashanian, M.; Williams, A. Pollutants Generated by the Combustion of Solid Biomass Fuels; Springer: London, UK, 2014; pp. 9-25. [CrossRef]

51. Giordano, G. Il Legno. Caratteristiche e Lavorazioni Fondamentali (The Wood, Fundamental Characteristics and Workings); Edizioni U.: Torino, Italy, 1980.

52. Demirbaş, A. Calculation of higher heating values of biomass fuels. Fuel 1997, 76, 431-434. [CrossRef]

53. Ciccarese, L. Effetto della cenere di legna sul substrato d'allevamento e sullo sviluppo in semenzali di douglasia e orniello (Effect of wood ash on growing medium and development in douglas and manna seedlings). Sherwood 2000, 53, 39-46.

54. Kehinde Fayemiwo, A.; Shola Awojide, H.; Comfort Beckley, A. Potential use of jatropha curcas stem for ethanol production. Int. J. Renew. Energy Res. 2013, 3, 68-72.

55. Shatalov, A.A.; Pereira, H. Influence of stem morphology on pulp and paper properties of Arundo donax L. reed. Ind. Crops Prod. 2002, 15, 77-83. [CrossRef]

56. Senelwa, K.; Sims, R.E.H. Fuel characteristics of short rotation forest biomass. Biomass Bioenergy 1999, 17, 127-140. [CrossRef]

57. Mantineo, M.; D'Agosta, G.M.; Copani, V.; Patanè, C.; Cosentino, S.L. Biomass yield and energy balance of three perennial crops for energy use in the semi-arid Mediterranean environment. Field Crops Res. 2009, 114, 204-213. [CrossRef]

58. Sharma, M.; Khan, A.A.; Puri, S.K.; Tuli, D.K. Wood ash as a potential heterogeneous catalyst for biodiesel synthesis. Biomass Bioenergy 2012, 41, 94-106. [CrossRef]

59. Pitman, R.M. Wood ash use in forestry-A review of the environmental impacts. Forestry 2006, 79, 563-588. [CrossRef] 
60. Būmane, S.; Poiša, L.; Adamovičs, A.; Platače, R.; Čubars, E. Melting temperature behavior of different energy crop ashes. In Environment. Technology. Resources, Proceedings of the 11th International Scientific and Practical Conference, Rezekne, Latvia, 15-17 June 2017; Rezekne Academy of Technologies: Rezekne, Latvia, 2017; Volume 1, p. 51. [CrossRef]

61. Pari, L.; Brambilla, M.; Bisaglia, C.; Del Giudice, A.; Croce, S.; Salerno, M.; Gallucci, F. Poplar wood chip storage: Effect of particle size and breathable covering on drying dynamics and biofuel quality. Biomass Bioenergy 2015, 81, 282-287. [CrossRef]

62. Pari, L.; Scarfone, A.; Santangelo, E.; Figorilli, S.; Crognale, S.; Petruccioli, M.; Suardi, A.; Gallucci, F.; Barontini, M. Alternative storage systems of Arundo donax L. and characterization of the stored biomass. Ind. Crops Prod. 2015, 75, 59-65. [CrossRef]

63. Perea-Moreno, A.-J.; Aguilera-Ureña, M.-J.; Manzano-Agugliaro, F. Fuel properties of avocado stone. Fuel 2016, 186, 358-364. [CrossRef]

64. Colantoni, A.; Longo, L.; Gallucci, F.; Monarca, D. Pyro-gasification of hazelnut pruning using a downdraft gasifier for concurrent production of syngas and biochar. Contemp. Eng. Sci. 2016, 9, 1339-1348. [CrossRef]

65. Gallucci, F.; Salerno, M.; Guerriero, E.; Amalfi, M.; Chiatti, G.; Palmieri, F. Research facility assessment for biomass combustion in moving grate furnaces. WASET Int. J. Chem. Mol. Eng. 2017, 4, 603-610.

66. Cambero, C.; Sowlati, T. Assessment and optimization of forest biomass supply chains from economic, social and environmental perspectives-A review of literature. Renew. Sustain. Energy Rev. 2014, 36, 62-73. [CrossRef]

67. Ciccioli, P.; Centritto, M.; Loreto, F. Biogenic volatile organic compound emissions from vegetation fires. Plant Cell Environ. 2014, 37, 1810-1825. [CrossRef] [PubMed]

68. SPE International Society of Unit Conversion Factors. Available online: http://www.spe.org/industry/unitconversion-factors.php (accessed on 11 May 2018).

69. EPA (United States Environmental Protection Agency). Energy and the Environment. Greenhouse Gases Equivalencies Calculator-Calculations and References. Available online: https:/ / www.epa.gov/energy / greenhouse-gases-equivalencies-calculator-calculations-and-references (accessed on 11 May 2018).

70. Telmo, C.; Lousada, J. Heating values of wood pellets from different species. Biomass Bioenergy 2011, 35, 2634-2639. [CrossRef]

71. Toscano, G. Agripellet quale soluzione per il riutilizzo energetico dei sottoprodotti agricoli (Agripellet as a solution for the energy reuse of agricultural by-products). In I Sottoprodotti Agroforestali e Industriali a Base Rinnovabile, Vol. 2-La Valorizzazione dei Sottoprodotti Nell'ambito Agro-Zootecnico, Industriale ed Energetico; Università Politecnica delle Marche: Ancona, Italy, 2013; pp. 75-84.

72. Risovic, S.; Dukic, I.; Vuckovic, K. Energy Analysis of pellets made of wood residues. Croat. J. For. Eng. 2008, 29, 95-108.

(C) 2018 by the authors. Licensee MDPI, Basel, Switzerland. This article is an open access article distributed under the terms and conditions of the Creative Commons Attribution (CC BY) license (http:/ / creativecommons.org/licenses/by/4.0/). 